\title{
Nucleic Acid Amplification Based Diagnostic of Lyme (Neuro-)borreliosis - Lost in the Jungle of Methods, Targets, and Assays?
}

\author{
Oliver Nolte*
}

Labor Dr. Brunner, Mainaustrabe 48 a/b, DE-78464, Konstanz, Germany

\begin{abstract}
Laboratory based diagnosis of infectious diseases usually relies on culture of the disease causing microorganism, followed by identification and susceptibility testing. Since Borrelia burgdorferi sensu lato, the etiologic agent of Lyme disease or Lyme borreliosis, requires very specific culture conditions (e.g. specific liquid media, long term culture) traditional bacteriology is often not done on a routine basis. Instead, confirmation of the clinical diagnosis needs either indirect techniques (like serology or measurement of cellular activity in the presence of antigens) or direct but culture independent techniques, like microscopy or nucleic acid amplification techniques (NAT), with polymerase chain reaction (PCR) being the most frequently applied NAT method in routine laboratories.
\end{abstract}

NAT uses nucleic acids of the disease causing micro-organism as template for amplification, isolated from various sources of clinical specimens. Although the underlying principle, adoption of the enzymatic process running during DNA duplication prior to prokaryotic cell division, is comparatively easy, a couple of 'pitfalls' is associated with the technique itself as well as with interpretation of the results.

At present, no commercial, CE-marked and sufficiently validated PCR assay is available. A number of homebrew assays have been published, which are different in terms of target (i.e. the gene targeted by the amplification primers), method (nested PCR, PCR followed by hybridization, real-time PCR) and validation criteria. Inhibitory compounds may lead to false negative results, if no appropriate internal control is included. Carry-over of amplicons, insufficient handling and workflow and/or insufficiently validated targets/primers may result in false positive results. Different targets may yield different analytical sensitivity, depending, among other factors, of the redundancy of a target gene in the genome. Performance characteristics (e.g. analytical sensitivity and specificity, clinical sensitivity and specificity, reproducibility, etc.) are, if available, only applicable to a specific assay, running in a specific laboratory. Finally, not only the NAT/PCR method itself, but also the process of DNA isolation from the specimen, is highly diverse and may have fundamental impact on the (expected) PCR result. Of concern are distribution effects of DNA, in particular, if only low numbers of bacteria/genomes are present in a sample, as it is the case for instance in cerebrospinal fluids.

For the ordering physician and for the patient requesting PCR analysis, these 'pitfalls' are usually invisible. As a consequence, the reported result (i.e. PCR negative or positive for B. burgdorferi) is hard to interpret, especially, if the reported PCR result is contradictory to the clinical diagnosis or other laboratory findings. Moreover, due to the high number of different assays in use, two laboratories, testing the same specimen, might come to different PCR results.

The current paper wants to summarize the available PCR/NAT assays for the detection of $B$. burgdorferi DNA in clinical specimens, with special attention to neurologic disorders, and to discuss the difficulties in PCR analysis and result interpretation, associated thereof. In view of growing numbers of patients who are diagnosed of having Lyme disease, and acknowledging a substantial growth in knowledge regarding other tick- or vector-borne pathogens, which might be able to induce symptoms comparable to Lyme (neuro-)borreliosis, efforts are urgently needed to standardize and harmonize methods for $B$. burgdorferi nucleic acid amplification.

Keywords: Polymerase chain reaction, Borrelia burgdorferi, Lyme disease, Lyme neuroborreliosis.

\section{INTRODUCTION}

The invention of polymerase chain reaction has revolutionized human diagnostics in many fields and in many

*Address correspondence to this author at the Labor Dr. Brunner, Mainaustrabe 48 a/b, DE-78464, Konstanz, Germany; Tel: +49-7531-8173-0; Fax: +49-7531-8173-99; E-mails: o.nolte@labor-brubber.de; oliver_nolte1965@yahoo.de ways. In infectious diseases, the confirmation of the presence of slow growing microbes like Mycobacterium tuberculosis dropped from 4 - 8 weeks (culture) to less than one day (modern real-time PCR assays). Especially in diseases, which are caused by uncultivable pathogens (e.g. Syphilis, caused by the spirochete Treponema pallidum or gastrointestinal disease caused by Tropheryma whipplei), the molecular detection of pathogen DNA by amplification is of great importance. PCR - or in general, nucleic acid amplification 
techniques, NAT or NAAT - protocols have been developed for a wide variety of pathogenic micro-organisms, and many of these protocols have taken their way into routine diagnostics. Moreover, NATs contribute to unraveling the nature of novel, emerging diseases, as was the case with the very recently identified, tick-transmitted SFTS (severe fever with thrombocytopenia syndrome) virus $[1,2]$. Since there is no doubt about the potential and impact of NAT on medicine and, in particular, diagnostics, a couple of obstacles and problems are stunningly still associated with DNA/RNA amplification. The current paper aims to provide a methodological overview and critical discussion about the power, the potentials, limitations and open questions of PCR with special attention to PCR-based diagnosis in Lyme disease patients.

\section{POLYMERASE CHAIN REACTION, SOME BASIC REFLECTIONS}

The underlying principle of PCR is comparatively simple. Mechanisms, which are well known from the DNA duplication prior to prokaryotic cell division, are adapted to synthesize novel DNA molecules in vitro. While during replication of DNA in vivo, the DNA polymerase needs a short ribonucleic acid oligonucleotide to start with, provided by the enzyme primase (reviewed in [3]), during PCR in vitro these starter molecules are synthetic (the oligonucleotide primers). These primers define the starting points for DNA synthesis anywhere on the bacterial genome, regardless of an origin of replication. The use of at least two, freely designable primers is the true power of the invention, since instead of linear duplication logarithmic increase of target molecules is enabled. As a consequence, the extremely low amounts of DNA present in clinical samples and invisible with routine diagnostic devices are pushed beyond the border of visibility, making them detectable by standard gel electrophoresis or by detection of fluorescence, which is emitted during real-time PCR.

With the advent of thermo stable DNA polymerase, a cyclic temperature profile for

i) melting the DNA double strand at $95 \mathrm{C}$ (the original template as well as the newly synthesized amplicons),

ii) enabling annealing of the primers at low temperatures (usually between 50 and $60 \mathrm{C}$ ) and

iii) allowing polymerase to elongate from the primers at ambient (72 C) temperatures, was possible, allowing access of PCR into medical diagnostics $[4,5]$.

Meanwhile, important modifications of the original protocol have been developed (Table $\mathbf{1}$ ) and the whole process of DNA extraction and amplification in a real-time fashion is highly automated.

Following a steep increase in newly developed PCR applications, published the years after first description, some serious limitations and obstacles became clear. Among those were difficulties, associated with the design of primers and the development of reliable PCR protocols, which are of interest for the technically interested user. A by no means complete collection of critical issues and parameters is provided in Table 2. In case, FDA (US Food and Drug Administration) cleared or IVD-CE (In Vitro Diagnostics Community European) marked assays are used as test format, the

Table 1. Overview Different PCR Formats/Assays

\begin{tabular}{|c|c|c|c|}
\hline Assay Format & Oligonucleotides & Analysis & Rating \\
\hline $\begin{array}{l}\text { classical PCR } \\
\text { format }\end{array}$ & 2 primers & electrophoresis, size of band & $\begin{array}{l}\text { not appropriate for diagnostics, comparatively low analytical sensi- } \\
\text { tivity, high risk of false positive results due to lack of specificity } \\
\text { confirmation (band size not indicative for the expected amplicon!), } \\
\text { acceptable, if downstream analysis (e.g. hybridization [see next } \\
\text { row] or sequencing is done) }\end{array}$ \\
\hline PCR/hybridization & 2 primers, one probe & $\begin{array}{l}\text { electrophoresis and subsequent } \\
\text { blotting, novel formats use reverse } \\
\text { blotting (probe immobilized on } \\
\text { blotting membrane or solid sup- } \\
\text { port) }\end{array}$ & $\begin{array}{l}\text { specificity of the expected band is confirmed by probe hybridiza- } \\
\text { tion, hybridization signal enhances sensitivity }\end{array}$ \\
\hline nested PCR & $\begin{array}{l}2 \text { primers first round, } \\
2 \text { internal primers } \\
\text { second round }\end{array}$ & gel electrophoresis, size of band & $\begin{array}{l}\text { enhanced specificity due to internal primer pairs which act as } \\
\text { probes, high risk of contamination (carry over) when opening the } \\
\text { tubes of the first round, high analytical sensitivity }\end{array}$ \\
\hline real-time PCR & $\begin{array}{l}2 \text { primers, fluores- } \\
\text { cent intercalating dye } \\
\text { (e.g. Cybergreen) }\end{array}$ & $\begin{array}{l}\text { analysis of fluorescence, emitted } \\
\text { during DNA-synthesis ("real- } \\
\text { time”), no confirmation of band } \\
\text { size }\end{array}$ & $\begin{array}{l}\text { enhanced analytical sensitivity due to fluorescence, low contamina- } \\
\text { tion risk as being carried out in closed reaction vials, no need to } \\
\text { open vials after PCR is finished, low specificity (staining of any } \\
\text { double stranded DNA molecule), analysis of melting curves for } \\
\text { increase in specificity }\end{array}$ \\
\hline real-time PCR & $\begin{array}{l}2 \text { primers, } 1 \text { or } 2 \\
\text { probes (depending } \\
\text { on the actual format) }\end{array}$ & $\begin{array}{l}\text { analysis of fluorescence, emitted } \\
\text { during DNA-synthesis ("real- } \\
\text { time”), no confirmation of band } \\
\text { size }\end{array}$ & $\begin{array}{l}\text { high analytical sensitivity due to fluorescence, low contamination } \\
\text { risk as being carried out in closed reaction vials, high specificity }\end{array}$ \\
\hline
\end{tabular}


office physician/general practitioner or the treating physician in a hospital setting does not necessarily need to know about such technical details, since the most critical variables are usually solved by the manufacturer prior to clearance or during routine perfective maintenance. There are, however, things which are important to know to correctly rate a "positive" or a "negative" on the laboratories' report in case, home-brew assays (i.e. laboratory developed and validated PCR formats) are used, as is the case for most if not all Borrelia PCR applications. In the following, some critical aspects of "Lyme Borrelia complex" PCRs are discussed.

\section{APPLICATIONS AND TARGET GENES}

Very early after introduction of NAT into medicine, first protocols for the detection of DNA of Borrelia burgdorferi were published, e.g. a culture based PCR [6], a PCR for detection of Borrelia DNA in erythema migrans [7] or for the diagnosis of Lyme neuroborreliosis [8]. Since B. burgdorferi sensu lato, the etiologic agent of Lyme borreliosis (LB, European term) or Lyme disease (LD, US term) is difficult to cultivate, PCR for the detection of Borrelia DNA became a favorite technique in the early 90 's of the $20^{\text {th }}$ century. Since that time, a couple of different assays have been published, although, unlike for other indications, a commercial, IVD-CE-marked/FDA-cleared and sufficiently validated assay is still not available. A couple of different targets have been addressed by primer/probe combinations, for instance the 16S-gene [9], the rrf-rrl intergenic region (also knonw as 5S-23S intergenic spacer region) [10,11], the flagellin gene [12], p66 outer membrane gene [13], the plasmid located ospA gene [7], or $L y-1$ (rpoC) [14]. As a consequence, different assays, mostly in house protocols, are in use throughout the laboratories. This lack of standardization is not only an academic problem but actually contributes to the difficulties in diagnosing $\mathrm{LB} / \mathrm{LD}$ and to define clear parameters for case definition based on the direct detection of the pathogen.

\section{“HOME-BREW-ASSAYS"}

In the early days of PCR, individual, home-brew protocols were used (i.e. each laboratory performed its own in house tests with its own primer pairs and protocols) but the number of available test components (i.e. consumables, extraction chemistry, amplification chemistry like nucleotides, polymerases and primers) was limited. With the increasing use of NAAT tests applied in infectious disease diagnostics, two developments have run in parallel: more and more companies provided consumables, enabling researchers and diagnosticians to tailor specific applications, and the increased workload due to increased use of NAAT in diagnostics forced laboratory staff and companies to think about methodological standardization and automation in order to allow for medium and high throughput diagnostics. A previously laborious procedure, the extraction of the nucleic acids from the specimen, was transferred from manual isolation (i.e. phenol/chloroform extraction and ethanol precipitation) to more standardized extraction over silica columns (i.e. for each patient the same amount or volume of specimen was extracted in always the same matter). Soon, the researcher or diagnostician had to choose from a plethora of different assays, available [15]. Following the increasing use of PCR in diagnostics, manufactures started to automate DNA extraction. Nowadays, two dozen or more instruments are on the market, allowing for (semi-)automated nucleic acid extractions from divers starting material and in each case with divers extraction kits for specific applications. This means that neither extraction nor amplification is really standardized. A high degree of standardization and comparability is only achieved when using IVD-CE-marked or FDA cleared assays for the detection. This is, for instance, the case with virus load determination in HIV diagnostics [16] for which highly standardized extraction and amplification protocols from two main manufacturers are available. For Lyme borreliosis diagnostics, however, no such assay is currently on hand, and published results of home-brew-assays are hard to compare. This may be exemplified by two PCR investigations, done 10 years apart from each other. GoOSKENS et al. (2006) [17] detected Borrelia DNA in 50\% of CSF-samples with pleocytosis but only in one CSF out of $15(7 \%)$, obtained from patients without pleocytosis but with neurological symptoms of Lyme disease and positive serology (PCR: ospA PCR, $500 \mu \mathrm{L}$ CSF, $100 \mu \mathrm{L}$ elution, real-time assay). Six of 16 (38\%) CSF from patients with acute Lyme neuroborreliosis (14/16 with pleocytosis) but $25 \%$ of $44 \mathrm{CSF}$ of patients with chronic neuroborreliosis yielded amplification with one of two slightly different ospA PCR's (PCR: $100 \mu \mathrm{L}$ CSF, $30 \mu \mathrm{L}$ elution, hybridization with radiolabeled probe) in the study of NocTON et al. (1996) [18]. One reason, among others, for the different sensitivity of both PCR might be the primer pair chosen, with the older primer pair [18] being the less specific one, as shown later in this paper.

\section{LYME BORRELIOSIS/LYME DISEASE}

Lyme borreliosis is without any doubt the most frequent bacterial disease, transmitted by an arthropod vector in Europe. However, since the disease is not always manifested with its characteristic symptoms, the actual incidence, even in countries were a compulsory registration exists, remains largely unclear. Improvements in diagnostics could contribute to better mapping the actual incidence of the disease. However, a general increase in the number of reported cases is obvious, as it is the case for the geographic area, in which LB is endemic [19]. While this increase might be a consequence of higher awareness, a true change in epidemiology cannot be ruled out.

The complex background of the multiorgan infectious disease LB is discussed elsewhere in this supplement. It should be noted, however, that beside some characteristic clinical manifestations and a couple of clear laboratory parameters, many patients suffer from more or less nonspecific symptoms, making a clinical, i.e. symptom based diagnosis difficult. In some cases, definite diagnosis of (neuro-)borreliosis is further hampered by a lack of indicative laboratory findings (e.g. lack of specific antibodies in serum and/or CSF, absence of pleocytosis). This has caused debate, what is an accepted case of (neuro-)borreliosis and what is more likely another infectious disease. A problem regularly encountered is the question whether a patient suffers (neuo-)borreliosis or if a different diagnosis is more likely, including the conclusion that the actual symptoms being observed might be the result of a non-infectious, per- 
haps mentally driven disorder. Enabling general practitioners and hospital physicians to draw the correct conclusion and the exact diagnosis for the patient is the challenge of laboratory medicine.

In case of infection or disease, B. burgdorferi sensu lato can be found in virtually any organ and any part of the human body, depending on the actual manifestation of Lyme disease. However, the amount of detectable bacteria in a given compartment of the body may be very low, and sometimes even too low to be actually detected by PCR.

\section{Borrelia Burgdorferi Sensu Lato}

The genus Borrelia can be divided into the relapsing fever group and the borreliosis group. SATZ (2010) [20] lists twelve Borrelia species as belonging to the borreliosis group (commonly referred to as B. burgdorferi senus lato) and an additional three species, causing borreliosis in animals, only. Two of these (geno-)species, Borrelia bissettii and Borrelia andersonii, are not listed in the "list of prokaryotic names with standing in nomenclature" (LPSN) [21], while an additional species, Borrelia bavariensis, proposed recently [22] is neither mentioned in [20] nor in the LPSN [21] as being an accepted species. Newly described and mentioned in the LPSN are Borrelia americana and B. carolinensis [23, 24] which are also listed in a current review [25], which includes 18 species in the "Lyme Borrelia complex".

Although the B. burgdorferi senu lato complex is large in terms of the number of described genospecies, only a few of them are indeed associated with LB/LD. These are the classical three genospecies Borrelia burgdorferi sensu stricto, Borrelia garinii, and Borrelia afzelii. In recent years it became evident, that a fourth species, Borrelia spielmanii, is causing disease, too. Three further species have been found in single LB cases, namely Borrelia valaisiana, B. bissettii and the recently described B. bavariensis. The taxonomic status of the latter, i.e. whether being a true species [22] or only a subtype of $B$. garinii is still subject of debate.

As a consequence, primers or primer/probe systems for amplification of borrelial DNA need to be specific for the relevant Borrelia species, or, if not, further characterization of amplicons is required (i.e. by sequencing). This may exemplified by the widely distributed "tick PCR" (a PCR which is applied to tick extracts to screen whether a tick was positive for Borrelia or not). Use of broad reactive primers like 5S - 23S rDNA intergenic spacer specific primers [10, 11] may pose the risk of leading to positive results even in the presence of non-pathogenic Borrelia or Borrelia for which the actual pathogenicity or degree of virulence is not known. This has been shown in our lab, when we demonstrated that by using the mentioned primer system DNA of the Borrelia LB2001 complex (related to a group of nonvirulent/non-pathogenic relapsing fever spirochetes) could successfully amplified from ticks, removed from humans in the South-Western parts of Germany (unpublished results). On the contrary, PCR assays targeting conserved regions only available in the classical three Borrelia genospecies are prone to fail amplification in cases, in which one of the newly described pathogenic Borrelia is associated with disease.

\section{PRIMER SEQUENCES}

Many of the available PCR protocols have been published a couple of years ago, sometimes soon after introduction of PCR into routine diagnostics. Since the primers define the specificity of the PCR they need to be designed and validated with care to avoid non-specific binding, leading to false positive or false negative PCR results [26, 27]. For the current paper, two primer pairs, one for a genomic and one for a plasmid encoded target were chosen and checked for specificity by using the NCBI BLAST tool (available online: http://blast.ncbi.nlm.nih.gov/Blast.cgi; option nucleotide blast), by BLASTing the primer sequences against the nucleotide collection (nr/nt), excluding models (XM/XP) and uncultured and/or environmental sample sequences.

The $L y-1$ primers (which actually bind to $r p o C$, a subunit of RNA polymerase and thus a genomic target [14]) were found to be specific for B. burgdorferi, B. afzelii, B. garinii, thus still being useful primers for amplification. One of the primers, specific for the plasmid encoded ospA (OspA18-39) [28], binds in silico to the genus Borrelia, but also Bacillus thuringiensis genome, Arabidopsis thaliana, Vitis vinifera, Medicago truncatula, the human chromosome 14, but shows reduced sequence homology (i.e. a couple of mismatches) even to a large number of Borrelia sp. isolates. Since further conditions like $\mathrm{MgCl}_{2}$ concentration, primer concentration, annealing temperature and even the type of polymerase used may influence and contribute to the specificity of a PCR (Table 2), a less specific primer like OspA18-39 poses the risk of non-specific amplification. Interestingly, two cases of false positive Borrelia PCR discussed in the literature [26, 27] both could be linked to ospA-PCRs. Although the reason for the misleading results is not clear, primers must not only be screened for specificity during development of an assay but also on a regular basis (e.g. annually), to avoid false positives.

Actually, the problem of older primer sequences is that the primers were designed and validated at that time on the basis of a very few, some from nowadays perspective even bad, sequences. Consequently, before using these primers in an own assay the oligonucleotide sequences should be checked carefully against available sequences. One of the ospA-primers published in 1991 [7] for instance aligns perfectly with some American Borrelia ospA sequences and some B. valaisiana sequences. To the majority of ospA sequences available today, however, these primers won't fit. In order to check for the accuracy of ospA-primers, a couple of published primer were aligned with the MEGA 5.0 software [29] to 43 publicly available ospA-sequences from B. burgdorferi s.s. (13), B. afzelii (10), B garinii (1), B. valaisiana (11), B. spielmanii (3), B. japonica (4) and Borrelia species (1) and checked for the number of mismatches (Table 3). Only the most recent primer pair used by GoOsKeNs et al (2006) [17] was found able to detect virtually all know Borrelia ospA sequences, using this in silico approach. Interestingly, the reported PCR assay showed a comparatively high sensitivity in CSF specimens with pleocytosis, although rather low volumes $(500 \mu \mathrm{L})$ were used for extraction. 
Table 2. Parameters Which have Significant Effects on the Performance of PCR Reactions, with Special Emphasis on Borrelia PCRs. The Table Mostly Reflects the Authors Experience, Some Aspects are in Addition Cited from Other Publications $[42,53,54,55]$

\begin{tabular}{|c|c|}
\hline Parameter & Critical Issues \\
\hline sample volume & $\begin{array}{l}\text { - definition of a minimum volume required to meet the minimum amount of genomes required for reproducible amplification } \\
\text { results, } \\
\text { - for samples with low cfu load, } 1 \mathrm{~mL} \text { should be the minimum amount of sample to start with }\end{array}$ \\
\hline sample type & $\begin{array}{l}\text { although DNA can be extracted from virtually any clinical specimen, some limitations exist: } \\
\text { - } \quad \text { tissue samples fixed with formaldehyde are generally less favorable than native specimens, } \\
\text { - the specimen should be taken from a site where an infection is likely }\end{array}$ \\
\hline extraction method & $\begin{array}{l}\text { - extraction kits or methods of different suppliers may not be comparable, DNA extracted with one procedure might lead to } \\
\text { optimal amplification in a given PCR while an extract of the same specimen but extracted with a different procedure might fail } \\
\text { to yield amplification }\end{array}$ \\
\hline target & $\begin{array}{l}\text { - } \quad \text { target must be sufficiently conserved to allow amplification of every isolate of the clinically relevant species but should be } \\
\text { sufficiently low conserved to allow for discrimination between clinically relevant and irrelevant species } \\
\text { - } \quad \text { redundant targets may be of advantage (although the analytical sensitivity can't be less than one genome per PCR) } \\
\text { targets which are encoded on genomic DNA seem to be superior over plasmid encoded targets since the faith of plasmids } \\
\text { following cell death is even less clear than for genomic DNA } \\
\text { a mRNA based target offers the opportunity to discriminate between "DNAemia” (simple presence of DNA) and true coloni- } \\
\text { zation/infection }\end{array}$ \\
\hline template DNA & $\begin{array}{l}\text { - inhibitors may be present even after extraction with commercial kits (for instance due to an excess amount of eukaryotic } \\
\text { DNA, which might lead to inhibition of PCR), the use of wrong containers may also lead to inhibition (heparinized blood has } \\
\text { a higher risk of causing subsequent inhibition than citrated blood or blood with EDTA as anticoagulant), } \\
\text { the volume of template used for amplification is critical: if low numbers of target DNA are expected, volumes of } 10 \mu \mathrm{l} \text { up to } \\
30 \mu \mathrm{L} \text { of template DNA may be advisable }\end{array}$ \\
\hline primers & $\begin{array}{l}\text { - } \quad \text { primers are the most critical components of PCR applications since they define specificity; } \\
\text { - } \quad \text { annealing characteristics greatly influence sensitivity (lower annealing temperature increase non-specific binding while higher } \\
\text { temperatures impede binding even to the matching target sequence), } \\
\text { annealing is influenced not only by the annealing temperature but also by the chemistry of the PCR reaction (e.g. the primer } \\
\text { concentration itself, the concentration/amount of template DNA present, } \mathrm{MgCl}_{2} \text { concentration, presence/absence of glycerol or } \\
\text { other components); } \\
\text { mismatches in primer sequence compared to target sequence may lead to reduced analytical sensitivity and specificity (mis- } \\
\text { matches in the central part of primers may show moderate effects, 5' mismatches may be without effect, depending on the } \\
\text { length of the primer whereas 3' mismatches can be detrimental (the correctly positioned 3' end with its free 3' hydroxygroup } \\
\text { is essential for elongation by DNA polymerases), } \\
\text { primers may form hairpins, dimers or multimers, depending on the sequence and the PCR-conditions, } \\
\text { - } \quad \text { multiple primers as in multiplex PCR's may reduce analytical sensitivity; } \\
\text { primer sequences should be checked in silico (BLASTing against nucleic acid sequence databases) on a regular basis to ensure } \\
\text { specificity (newly published sequences may not be targeted by primers due to genetic variations or novel strains/variants de- } \\
\text { tected; also, newly published sequences of, for instance, saprophytic bacteria might cause concern, that cross-reaction might } \\
\text { be possible under certain circumstances; primer sequences should be than adapted accordingly and the PCR needs re- } \\
\text { validation!) }\end{array}$ \\
\hline PCR chemistry & $\begin{array}{l}\text { - in addition to } \mathrm{MgCl}_{2} \text { a couple of components have influence on the amplification efficacy; some additives may augment } \\
\text { amplification while other may increase specifity. }\end{array}$ \\
\hline
\end{tabular}

\section{PLASMIDS OF BORRELIA}

The genus Borrelia is belonging phylogentically to the Gram-negative bacteria and here into the order Spirochetales. Close relative is the Genus Treponema with the syphilis causing spirochete T. pallidum. At this time, a couple of whole genomes of $B$. burgdorferi sensu stricto as well as genomes of B. garinii and B. afzelii have been sequenced with the genome sequence data being available in public databases. It is likely that in the near future more genomes will become available, in particular for those Borrelia species which are currently not sequenced. The genomes of the sequenced $B$. burgdorferi are comparatively small, being less than 1 million bp in size. However, some genospecies of the complex have accumulated extra genetic material in the form 
of up to twelve linear and nine circular plasmids, which can account for up to another $600.000 \mathrm{bp}$, a phenomenon nearly unprecedented in the bacterial kingdom [30].

\section{TARGET IMBALANCE}

Some plasmids may be single copy plasmids while other plasmids may be present in more than copy per Borrelia cell. Consequently, a plasmid target based PCR would have a higher chance of yielding a positive result than a single copy gene, located on the bacterial chromosome. This was shown as early as 1994 [9] and was named 'target imbalance'. In culture negative clinical specimens of 19 patients, plasmid encoded targets (ospA/ospB) were detected by PCR in each case, while PCR for the $16 \mathrm{~S}$ target yielded amplification in eight, and PCR targeting the flagellin gene in nine cases (eleven specimens positive in one of both PCRs). The authors concluded that "the most sensitive and reliable targets for PCR detection of B. burgdorferi lie on extrachromosomal elements" [9] although they acknowledged that plasmids may be released in membrane vesicles released by Borrelia [31].

\section{PLASMIDS AND GENOME PLASTICITY}

Many of the plasmids occurring in species of the "Lyme complex Borrelia" are already sequenced. Nevertheless, novel variants of plasmids are described in the most recent literature as was the case for a large linear plasmid of B. spielmanii [32], a genospecies which appears to be associated with skin manifestations [33]. At least during prolonged culture and repeated passage, Borrelia might even loose plasmids [34], illustrating both, the high genetic diversity of the complex as well as the urgent need for more research in order to get a more detailed and comprehensive view about the genetic material and genomic plasticity of the B. burgdorferi complex.

PCR assays have been described for both, plasmid coded targets and targets located on the borrelial chromosome. Plasmids in general constitute additional genetic material and a given bacterial species may acquire plasmid DNA from external sources or via direct transmission from a donor bacterium. Hence, many plasmids are mobile and may easily be transferred between strains of a particular species. Some plasmids, however, are even more promiscuous, as is the case with the blaNDM -1 , conferring the $ß$-lactam resistance of New Delhi metallo-ß-lactamase-1 type. NDM-1 was first reported from a Klebsiella pneumoniae but has spread into virtually all members of enterobacteriaceae and the nonfermenter within only three years, illustrating the capacity to not only cross a species- but also a genus-border (discussed in [35]).

For the ospC coding plasmid transferability by means of lateral gene transfer within the $B$. burgdorferi complex has been shown [36], although the exact mechanism, by which genetic material is exchanged, remains unknown. Since plasmid containing membrane blebs are released by Borrelia [31, 37] a potential vehicle for genetic exchange might already be identified. If, however, for instance the ospA carrying plasmid of $B$. burgdoferi would be transferable, this would have great impact on the interpretation of PCR results.
Associated with the question of plasmid mobility is the possible persistence of plasmid DNA in tissue or body fluids. Once a Borrelia infection is successfully fought by the immune system, the cellular debris is cleared from the body. Many authors have shown, that during the course of an infection, B. burgdorferi PCR from urine is positive [38-41]. Genomic DNA, however, can be detected even after clearance of infection. Li et al. (2011) [42] reported in patients with antibiotic-refractory arthritis persistent genomic DNA causing positive PCR for up to 11 month. The authors used a smart approach in which they not only looked for genomic DNA but also for (instable) mRNA, which can be assumed to be present only during active borreliosis (see below). At least at this time, persistence of plasmids after clearance of Borrelia infection cannot be excluded with sufficient reliability. This would probably mean that even in cases in which Borrelia infections may not have caused disease, a plasmid-based PCR (i.e. a PCR targeting ospA or ospB) would stay positive for an unknown period of time.

\section{DNA VS. mRNA}

The persistence of DNA (either as 'dead' microorganisms in tissue or phagocytic cells, as DNA remnants in tissues or fluids, or as DNA containing membrane vesicle) raises a couple of questions. What is the actual relevance of detected DNA by means of a positive PCR? Is a positive amplification a true or reliable surrogate for active disease/infection? What, if a PCR signal is only a result of remnant DNA, comparable to what is known as DNAemia in molecular sepsis diagnostics [43] and how can 'dead DNA' be discriminated from vital or at least living microorganisms? Recently, Li et al. (2011) [42] reported that in eight of eleven samples from erythema migrans not only Borrelia DNA was amplified but also Borrelia specific messenger RNA (mRNA). In eleven samples from synovial fluids, however, no mRNA was detected. While DNA is comparatively stable, mRNA is a transient molecule with short half-life, synthesized more or less continuously by RNA-Polymerase during protein biosynthesis [44]. Consequently, the detection of this molecule rules out the presence of remnant DNA ("DNAemia”). This approach is truly worth to be further investigated. Although laborious and not suitable for routine application at this time, (co-)amplification of mRNA would be a true surrogate marker for active infection. Whether an infection is the reason for the observed symptoms or disease remains a question of clinical diagnostics in anyway.

\section{DNA EXTRACTION}

The extraction of nucleic acids from the clinical specimen is one of the most critical issues, since the amount and the quality of target DNA yielded determines the outcome of the PCR process. Target DNA may be lost during extraction or poor extraction procedures may yield DNA 'contaminated' with inhibitory components. Although standardized procedures are available, e.g. the column based technologies, the magnetic bead based separation and others there is indeed a lack of standardization in the procedures for nucleic acid isolation. A recent market analysis of the 'Laborjournal', a German lab magazine, revealed more than 40 differ- 
Table 3. Specificity of Published ospA Primers. OspA Specific Primers Available from the Literature (Reference in Column 1) were Aligned Against 43 ospA Sequences of Different Borrelia Species, Using MEGA 5.0 Software (TAMURA et al 2011). Bold Faced Upper-case Letters (A/T/C/G) Indicate that the Particular Base Matches to All 43 Aligned Sequences While Lower Case Standard Letters $(\mathrm{a} / \mathrm{t} / \mathrm{C} / \mathrm{g})$ Indicate that There is a Mismatch with at Least one Sequence of the Alignment; r/R Means Degenerated Base Position C or T, the Elongation Direction is Indicted by or 4 . The Primer Sequences were Taken from the References but Adjusted (i.e. Reversed) where Necessary to Fit for the MEGA Alignment. Primer Names as Given in Column 2 are Taken from the Original Publications. In the Last Column, a Comment is Which Provides Additional Information about the Specificity, i.e. if A primer Pair was Designed Specifically for a Subset of Borrelia Isolates

\begin{tabular}{|c|c|c|c|}
\hline Authors [Reference] & Primer Names & Primer Names/Sequences & Comment \\
\hline Guy \& Stanek 1991 [7] & $\begin{array}{l}\text { primer pair } 1 \\
\text { N1: } \\
\text { C1: } \\
\text { primer pair } 2 \\
\text { N2: } \\
\text { C2: }\end{array}$ & $\begin{array}{l}\text { GAgCTtAAAGGAACTTCTGATAA } \\
\text { \ACAATTACagTacAACaATAC } \\
\text { AtGGaTCtGGagtaCTtGAA } \\
\text { \AgAaGgaactgtTacTttaag }\end{array}$ & $\begin{array}{l}\text { The primer/probe system is adapted to American } \\
\text { B. burgdorferi isolates, to which all oligonucleo- } \\
\text { tides show } 100 \% \text { identity. }\end{array}$ \\
\hline Demaerschalck et al. [56] & $\begin{array}{l}\text { OspA_fw: } \\
\text { OspA_rw: }\end{array}$ & $\begin{array}{l}\text { aATAGGTCTAaTAatAGCCTTAATAGC } \\
\text { 4 tTtTCAAAGAAGATGgcaaAACAc- } \\
\text { TAG }\end{array}$ & $\begin{array}{l}\text { The primers are specific for the three 'classical' } \\
\text { genospecies, when aligned only to them the number } \\
\text { of mismatches is } 2 \text { for OspA_fw and } 4 \text { for } \\
\text { OspA_rw. }\end{array}$ \\
\hline Gooskens et al. [17] & $\begin{array}{l}\text { BORs: } \\
\text { BORas:B } \\
\text { OR-TQ (probe): }\end{array}$ & $\begin{array}{l}\text { АтAтTTATTGGGaAtAGGTcTAatAт } \\
\text { «CTTGTAAGrAAAGAAAAagAcAAaG } \\
\text { AAgCAAAATGTTAGCagcCTtGA }\end{array}$ & \\
\hline Nocton et al. [57] & $\begin{array}{l}\text { OspA4: } \\
\text { OspA2: } \\
\text { OspA3(probe): }\end{array}$ & $\begin{array}{l}\text { CtgcagctTGGaattcaggcacTtc } \\
\text { Ggtcagcagttgaaattacaaaac } \\
\text { CagTacAAcaaTAcgACtCaaatGgc }\end{array}$ & $\begin{array}{l}\text { The primer/probe system is adapted to American } \\
\text { B. burgdorferi isolates, A3 and A4 show } 100 \% \\
\text { homology, while A } 2 \text { has two mismatches. The } \\
\text { shown primer/probe system is Set } 1 \text { in the original } \\
\text { publication of } 1994\end{array}$ \\
\hline Nocton et al. [57] & $\begin{array}{l}\text { OspA149: } \\
\text { OspA319: } \\
\text { OspA6'(probe): } \\
\text { OspA6 ( } 2^{\text {nd }} \text { probe): }\end{array}$ & $\begin{array}{l}\text { ATGAAAAAATATTTATTGGGaAT } \\
\text { \ ACAGTAGACAAgCTTGAgCTtAAAG } \\
\text { GCATGtAAgCAAAATGTTAGC } \\
\text { ATTGGGaATAGGTCTAaTATtAGCCT }\end{array}$ & $\begin{array}{l}\text { The primer/probe system is also adapted to Ameri- } \\
\text { can B. burgdorferi isolates, A319 has one mis- } \\
\text { match, A6 two while A149 and A6' show } 100 \% \\
\text { homology. Primer/probe system OspA149/319/6' is } \\
\text { Set } 2 \text { in the original publication of } 1994 \text {, while } \\
\text { OspA149/319/6 is Set } 3\end{array}$ \\
\hline $\begin{array}{l}\text { Priem et al. (“ospA/B”- } \\
\text { primers) [28] }\end{array}$ & $\begin{array}{l}\text { outer primer } 1 \text { : } \\
\text { outer primer } 2 \text { : } \\
\text { nested primer } 1 \text { : } \\
\text { nested primer } 2 \text { : }\end{array}$ & $\begin{array}{l}\text { TTGTAAgCAAAGAAAAaaA } \\
\text { ttaaaaacGCTTTaAAATAA* } \\
\text { GAcGgcAAgTACgatCTAgctG } \\
\text { \ttaaAgAaGgaactgtaacT }\end{array}$ & $\begin{array}{l}\text { The primer/probe system is also adapted to Ameri- } \\
\text { can } B \text {. burgdorferi isolates, primer } 1 \text { fits } 100 \% \text {, } \\
\text { nested } 1 \text { shows } 3 \text { mismatches, nested } 2 \text { one mis- } \\
\text { match and primer } 2 \text { fits } 100 \% \text { is strain Fort Sheri- } \\
\text { dan } 36 \text { is omitted. * Outer primer } 2 \text { is shown re- } \\
\text { versed in the original paper. }\end{array}$ \\
\hline
\end{tabular}

ent providers, offering more than 250 kits for RNA extraction, covering virtually every source of possible specimen [15]. Although no market analysis for DNA extraction kits was done, one can assume that the spectrum is comparable.

Most suppliers of commercial kits have focused on adapting the extraction procedure to modern automated solutions. Depending on the extraction kit used and the automat available, volumes between $200 \mu \mathrm{L}$ and $1 \mathrm{~mL}$ are being processed. However, no reliable method is available to extract and concentrate the DNA of pathogens, present with 1 cfu or less per mL, from a volume, necessary to allow reproducible PCR results. If one assumes that for a reliably positive PCR at least 5 copies of the target DNA are required, 5 $\mathrm{mL}$ of body fluids must be extracted and concentrated in a final volume of $10 \mu \mathrm{L}$ or less (for a single PCR to be done from the extract). Extraction with a high concentration factor 
(i.e. large starting amount and low extraction volume) can be done, but the lower the extraction volume the lower the extraction efficacy. Furthermore, such procedures cannot be adapted for automated extraction. However, in the routine laboratory, which processes a large number of nucleic acid extractions per working day, procedures are usually adapted to automation. If the starting material is blood, the final extract will have as much of human DNA that amplification of the target DNA, even if present in sufficient amounts, is likely being inhibited by the presence of the vast amount of human DNA.

Assuming a detection limit of 5 genomes per PCR (single copy target) and a cfu load of 25 genomes per mL, a standard extraction using column based technology would start with $200 \mu \mathrm{L}$ of starting material (5 genomes) eluted in $100 \mu \mathrm{L}$ (giving a final concentration of 1 genome per $20 \mu \mathrm{L}$ ). Standard applications in an amplification volume of $50 \mu \mathrm{L}$ usually run with $5 \mu \mathrm{L}$ of extract and must therefore lead to a negative result. If one would instead use a starting volume of $5 \mathrm{~mL}$ (125 genomes), and extract in $25 \mu \mathrm{L}$ the final concentration would be 5 genomes per $\mu \mathrm{L}$ and a standard PCR would result in amplification, even of a single copy gene. This theoretical calculation assumes an extraction efficacy of $100 \%$, which is not realistic. In case, a high cfu load is present in an infected tissue or an organ, standardized protocols, even with starting volumes of $200 \mu \mathrm{L}$ are sufficient. The available literature about PCR assays for the detection of Borrelia from cerebrospinal fluids, synovial fluids or urines highlights the necessity of using large volumes for extraction in order to increase the sensitivity of PCR.

\section{LOW AMOUNTS OF DNA IN LIQUID SAMPLES AND NECESSITY TO USE LARGER VOLUMES FOR EX- TRACTION}

SCHMIDT et al. (1996) [41] used large amounts of urine volume for the detection of Borrelia DNA (targeting the flagellin gene in a heminested approach). Starting with $8 \mathrm{~mL}$ of urine, concentration of a factor 13 was achieved by dissolving the pellet after centrifugation in $600 \mu \mathrm{L}$ PBS. A further up concentration of a factor 6 was than achieved by a second centrifugation step after which the pellet was dissolved in a volume of $50 \mu \mathrm{L}$. This was mixed with an equal volume of Chelex-100 and $10 \mu \mathrm{L}$ of the resulting supernatant were used for PCR. The limit of detection when using a nested PCR approach (25 cycles first PCR, followed by 35 cycles of the second PCR) was less than 5 genomes per PCR, equaling 50 borrelia in the original $8 \mathrm{~mL}$ urine volume. The extraction protocol was modified later on [38, 45] (DNAzol, starting with $10 \mathrm{~mL}$ of urine, the pellet being resuspended in $1 \mathrm{~mL}$, than recentrifuged, and resuspended in $100 \mu \mathrm{L}$ ). Using the same primers as in [41] the limit of detection was also found to be 5 genomes per PCR. Positive results were only obtained after DNA preparation with DNAzol (10 mL starting volume) but not with other methods tested (such as QIAGEN columns, which use $0.2 \mathrm{~mL}$ as starting volume). In a subsequent work, the group further analyzed the problem of low DNA amounts in liquid samples by again using urine and demonstrated that a one-step real-time PCR assay for the detection of the Borrelia flagellin gene was less sensitive when compared to a nested PCR protocol [46]. While the nested protocol yielded positive PCR results with as low as five Borrelia genomes per PCR, the one-step real-time protocol was found to be positive reproducibly, when 50 to 100 genomes (DNAzol extraction) or 500 genomes (QIAamp and Roche extraction kits) were present per PCR (results from spiked urines).

Large volumes of urine $(10-50 \mathrm{~mL})$ and synovial fluids (1 - $10 \mathrm{~mL}$ ) were used in another study [28]. Following centrifugation the resulting pellet was washed and subsequently used for an alkaline lysis method. Applying this large volume DNA extraction method to samples obtained from patients with Lyme arthritis and Lyme neuroborreliosis, diagnostic sensitivities of $91 \%$ and $87 \%$ could be achieved. These high rates of sensitivity can be explained by the use of two types of specimen per patient (synovial fluid/urine or CSF/urine) and the use of two different PCR assays. Consequently, when using low volumes of sample material, the diagnostic sensitivity of PCR was found to be low. ZBINDEN and colleagues (1994) [47] reported two out of twelve patients being positive by PCR when using $50 \mu \mathrm{L}$ of CSF for DNA extraction.

CERAR et al. (2008) [48] amplified DNA from $11.9 \%$ of 135 blood- and of $15.4 \%$ of 156 CSF-samples obtained from patients with Lyme neuroborreliosis, suscpected LNB and other clinical diagnosis. Two nested PCR assays were used, one, targeting the $r r f-r r l$ intergenic region (also known as $5 \mathrm{~S} / 23 \mathrm{~S}$ intergenic region) $[10,11]$, the other one targeting the ospA gene of predominantly American Borrelia isolates [7]. Ten of 48 (21\%) CSF-samples of patients with neuroborreliosis yielded a positive PCR result in at least one of both PCR assays. For the $r r f-r r l$ region, the authors cited a previous work [11]. However, since in [11] only a normal, i.e. not a nested PCR was published, the nature of the outer primer pair (SPA1/SPA2) in the later work [48] remains obscure. The authors concluded, that the detection of Borrelia DNA (or RNA) from clinical specimens is far from being standardized. Since real-time assays become more and more a standard procedure, the MIQE guidelines [49] provide a good basis for the future development and publication of these assays.

\section{STANDARDIZATION IS OBLIGATE}

The examples discussed above illustrate that the absolute necessity for having a reliable method for nucleic acid amplification techniques (which includes the type or suitable starting material, processing of large volumes if necessary, extraction process, sufficiently validated and accepted primer/probe systems, and finally the amplification and detection), in order to provide unambiguous diagnostic results. That this is not wishful thinking documents the PCR for detecting HIV RNA in patients' blood plasma [16]. Following optimization, two assays define nowadays the standard, reaching a limit of detection of below 40 genomes per $\mathrm{mL}$. The development of such assays needs the engagement of partners from industry. Validation of such (commercialized) assays need clear disease and case definition criteria, meaning, that such assays are perhaps limited to a subset of patients. However, without standardized and rigorously validated PCR assays, the discussion on the necessity of compulsory reporting is obsolete, since reliable reporting of disease cases not only needs an accepted clinical case defini- 
tion but also an accepted and validated process of direct pathogen detection (either culture or nucleic acid amplification).

Why further is standardization of PCR as a direct detection method for Borrelia DNA important?

\section{RE-IMBURSEMENT SYSTEM (GERMANY)}

The following is specific for German patients, only. Detection of Borrelia DNA is not subject of reimbursement by the public healthcare insurance provider (collectively named 'statutory health insurance fund', abbreviated SHIF for the remainder of the paper) in Germany. If a patient suffers symptoms of disease, specific for borrelosis, a basic serology (i.e. ELSIA) is reimbursed. If the ELSIA is positive, a conformational test (i.e. Western- or immunoblot) is also reimbursed. Also part of the reimbursement system is the culture of the spirochetes. The overall amount of money granted by the reimbursement system does not cover, however, even the cost of the culture material. If a Borrelia-PCR is requested or necessary, however, this has to be paid for by the patient itself. SHIF in Germany takes care for about 70 million people.

For parameters, not yet part of the reimbursement system of the SHIF, a complex routine exists to enable medical progress to be made accessible for those, not being privately insured. If, however, a specific laboratory parameter (usually termed 'patient relevant innovation' or 'medical innovation') is found to be useful by companies, developing novel diagnostics or by medical or scientific associations, these stakeholders are allowed to propose this 'innovation' (by submitting a detailed application) to the so-called "National Association of Statutory Health Insurance Physicians" (German: Kassenärztliche Bundesvereinigung" - $\mathrm{KBV}^{1}$ ), which, in turn performs a rigorous check of the application [50]. If the proposed innovative parameter is found to be important and the application fulfills all criteria, the KBV may than apply for a consultancy claim at the G-BA (The German Health Care System and the Federal Joint Committee, German: Der Gemeinsame Bundesausschuss). The G-BA will than follow a complex routine process to decide whether an innovative parameter can be accepted as benefit for the catalogue of the SHIF. The KBV, which receives the applications for novel or innovative parameters, has published a guideline about the minimum information needed, to submit the application and provides some examples of the necessary information (SCHIFFNER R. Criteria used by the KBV-innovation service for decision on proposals of medical, non-pharmaceutical innovations to the German Federal Joint Committee (G-BA). 2008; Poster T-117 http://www.kbv.de/veranstaltungen/ innovationsservice.html (download page for accessing the poster; last accessed: July $\left.16^{\text {th }} 2011\right)$ ).

For the current paper the above outlined procedure to include improvements in medical diagnostics in the catalog of benefits illustrates that only highly standardized and rigorously validated PCR procedures may have a chance of success. Therefore, every effort must be undertaken, to improve PCR performance with the goal to have accepted

\footnotetext{
1 for an English summary about this association please go http://www.kbv.de/78.html
}

methods available which allow for reproducible results. The results generated with such standardized and accepted methods need to match the clinical diagnosis. With respect to this, clear criteria are also required to classify whether a given clinical specimen such a CSF is suitable for PCR diagnosis (i.e. sufficient volume of body fluid or size of biopsy, adherence to pre-analytical procedures including time of and conditions during transportation). These criteria exist in principle and clinicians as well as laboratories are advised to use them appropriately.

\section{COMPULSORY REPORTING OF CASES}

In the European Community, only a few countries have implemented compulsory reporting for Lyme-disease cases [19]. In Germany, borreliosis is a notifiable disease in five of 16 states; another two states are prepared to start notification. Some organizations in Germany favor a general reporting system. However, clear criteria are required in order to implement an effective reporting. There should be an effective measurement to discriminate between cases which might be a borreliosis (but, in fact, are a different disease, presenting with similar symptoms - and requiring different treatment) and those which are true cases. For the occurrence of an erythema migrans following tick bite being an accepted case definition criterion, reporting and coverage of Lyme disease epidemiology could by enhanced by an optional (!) $B$. burgdorferi PCR from the erythematous lesion. PCR confirmation would lead to a much higher quality of the reporting data and would provide important improvements in case management, since PCR enables the fast and reliable identification of the genospecies involved. An ultimate necessity of such a PCR supported reporting system would be, however, a standardized and validated amplification assay.

\section{CONCLUSION}

Without doubt NAAT for the detection of Borrelia genetic material in clinical specimens is a highly important diagnostic tool to aid the clinician or general practitioner/office physician in finding or ensuring a definite diagnosis of $L B / L D$ in the suffering patient. Due to the lack of commercially available and sufficiently validated assays, many different PCR protocols are in use. While each published protocol may have its benefit for a specific patient population, a rigorously validated and standardized PCR assay is needed in order to face the actual challenges in diagnosing vector borne infectious diseases. Currently, caution is required when choosing a PCR protocol from the published ones, since - as shown for the ospA targeting PCRs - some primers may only detect a subset of the known B. burgdorferi strains. An ospA PCR with primers designed on older B. burgdorferi s.s. ospA sequences may be sufficiently specific when used in the US but not in Europe.

While standardization is required regarding the optimal volume of a liquid or solid clinical specimen (i.e. what is the minimal/optimal volume of CSF, urine, tissue to be processed) the Standardization in nucleic acid extraction (i.e. optimization to automated solutions) has not necessarily contributed to better diagnostics. Since automated formats often use comparatively small volumes of specimen to start with (typically $200 \mu \mathrm{L}$ ), the low cfu load of Borrelia in clini- 
cal specimens might make larger volumes necessary (minimum $1 \mathrm{~mL}$, up to 10 or more $\mathrm{mL}$ for urine).

A couple of different micro-organisms are harbored by ticks and many of them may be principally transmitted during tick bite. Although B. burgdorferi is the best studied among these organisms, some other may also cause disease, probably with symptoms similar to those seen in LB/LD patients. However; in order to provide the most appropriate treatment for the patient, an accurate diagnosis is needed. While so-called co-infecting or co-transmitted microorganisms become increasingly appreciated, robust laboratory procedures are required to allow the reliable (and reproducible) detection of the DNA (or RNA) of the infecting micro-organism.

Of particular interest is the novel concept of combining classical PCR on multiple loci with electrospray ionization mass spectrometry (PCR/ESI-MS) [51, 52]. This PCR is currently being commercialized, although as a vector-borne assay, only, but may provide a sensitive and specific PCR method for use in human diagnostics in the near future. Subsequent work by the same group aims on detecting and identifying Borrelia directly from blood of patients with erythema migrans (EsHOO M, CROWDER C., Rounds $\mathrm{M}$, Mathews H, SOlOSKI M, SchwarzWALder A, SCHUTZER S, AucotT J (2011): Conference abstract O358: "Direct detection of early Lyme borreliosis from whole blood”. $21^{\text {st }}$ European Congress of Clinical Microbiology and Infectious Diseases $-27^{\text {th }}$ International Congress of Chemotherapy, May $7^{\text {th }}-$ May $10^{\text {th }} 2011$, Milan, Italy).

Novel PCR assays, commercial or not, should have been assessed for their clinical and analytical sensitivity and specificity before being used in routine diagnostics. With advanced molecular assays at hand and in companion to clinical diagnostics, robust case definition criteria of acute disease should become accepted, which in turn should allow high quality compulsory reporting.

\section{CONFLICT OF INTEREST}

The authors confirm that this article content has no conflicts of interest.

\section{ACKNOWLEDGEMENT}

None declared.

\section{REFERENCES}

[1] Feldmann H. Truly emerging - a new disease caused by a novel virus. N Engl J Med 2011; 364: 1561-3

[2] Yu XJ, Liang MF, Zhang SY, et al. Fever with thrombocytopenia associated with a novel bunyavirus in China. N Engl J Med 2011; 364: 1523-32

[3] Larson MA, Griep MA, Bressani R, Chintakayala K, Soultanas P, Hinrichs SH. Class-specific restrictions define primase interactions with DNA template and replicative helicase. Nucleic Acids Res 2010; 38: 7167-78

[4] Saiki RK, Scharf S, Faloona F, et al. Enzymatic amplification of beta-globin genomic sequences and restriction site analysis for diagnosis of sickle cell anemia. Science 1985; 230:1350-4

[5] Mullis KB, Faloona FA. Specific synthesis of DNA in vitro via a polymerase-catalyzed chain reaction. Methods Enzymol 1987; 155: 335-50.
[6] Rosa PA, Schwan TG. A specific and sensitive assay for the Lyme disease spirochete Borrelia burgdorferi using the polymerase chain reaction. J Infect Dis 1989; 160: 1018-29

[7] Guy EC, Stanek G. Detection of Borrelia burgdorferi in patients with Lyme disease by the polymerase chain reaction. J Clin Pathol 1991; 44: 610-1

[8] Keller TL, Halperin JJ, Whitman M. PCR detection of Borrelia burgdorferi DNA in cerebrospinal fluid of Lyme neuroborreliosis patients. Neurology 1992; 42: 32-42

[9] Persing DH, Rutledge BJ, Rys PN, et al. Target imbalance: disparity of Borrelia burgdorferi genetic material in synovial fluid from Lyme arthritis patients. J Infect Dis 1994; 169: 668-72

[10] Schwartz I, Wormser GP, Schwartz JJ, et al. Diagnosis of early Lyme disease by polymerase chain reaction amplification and culture of skin biopsies from erythema migrans lesions. J Clin Microbiol 1992; 30: 3082-8

[11] Postic D, Assous MV, Grimont PAD, Baranton G. Diversity of Borrelia burgdorferi sensu lato evidenced by restriction fragment length polymorphism of rrf (5S)-rrl (23s) intergenic spacer amplicons. Int J Syst Bacteriol 1994; 44: 743-52

[12] Lebech A-M, Hansen K. Detection of Borrelia burgdorferi DNA in urine samples and cerebrospinal fluid samples from patients with early and late Lyme neuroborreliosis by polymerase chain reaction. J Clin Microbiol 1992; 30: 1646-53

[13] Rosa PA, Hogan D, Schwan TG. Polymerase chain reaction analyses identify two distinct classes of Borrelia burgdorferi. J Clin Microbiol 1991; 29: 524-32

[14] Goodman JL, Jurkovich P, Kramber JM, Johnson RC. Molecular detection of persistent Borrelia burgdorferi in the urine of patients with active Lyme disease. Infect Immun 1991; 59: 269-78

[15] Anonymous. Produktübersicht RNA Isolierung. Laborjournal 2010; 5: $57-64$

[16] Sloma CR, Germer JJ, Gerads TM, et al. Comparison of the Abbott realtime human immunodeficiency virus type 1 (HIV-1) assay to the Cobas AmpliPrep/Cobas Taqman HIV-1 test: workflow, reliability, and direct costs. J Clin Microbiol 2009; 47: 889-95

[17] Gooskens J, Templeton KE, Claas EC, van Dam AP. Evaluation of an internally controlled real-time PCR targeting the ospA gene for detection of Borrelia burgdorferi sensu lato DNA in cerebrospinal fluid. Clin Microbiol Infect 2006; 12: 894-900

[18] Nocton JJ, Bloom BJ, Rutledge BJ, et al. Detection of Borrelia burgdorferi DNA by polymerase chain reaction in cerebrospinal fluid in Lyme neuroborreliose. J Infect Dis 1996; 174: 623-7

[19] Lindgren E, Jaenson TGT. Lyme borreliosis in Europe: influences of climate and climate change, epidemiology, ecology and adaptation measures. WHO Europe. EU/04/5046250, WHOLIS no.: E89522 2006 Available: http://www.euro.who.int/en/what-wepublish

[20] Satz N. Klinik der Lyme-Borreliose. $3^{\text {rd }}$ ed. Bern: Verlag Hans Huber 2010

[21] Euzéby JP. List of Prokaryotic names with Standing in Nomenclature. 2011 (Available: http://www.bacterio.cict.fr/ [last Accessed: July $14^{\text {th }} 2011$.

[22] Margos G, Vollmer SA, Cornet M, et al. A new Borrelia species defined by multilocus sequence analysis of housekeeping genes. Appl Environ Microbiol 2009; 75: 5410-6

[23] Rudenko N, Golovchenko M, Lin T, Gao L, Grubhoffer L, Oliver Jr. JH. Delineation of a new species of the Borrelia burgdorferi sensu lato complex, Borrelia americana sp.nov. J Clin Microbiol 2009; 47: 3875-80

[24] Rudenko N, Golovchenko M, Lin T, Gao L, Grubhoffer L, Oliver Jr. JH. Borrelia carolinensis sp. nov., a novel species of the Borrelia burgdorferi sensu lato complex isolated from rodents and a tick from the south-eastern USA. Int J Syst Evol Microbiol 2010; 61: 381-3

[25] Stanek G, Reiter M. The expanding Lyme Borrelia complex-clinical significance of genomic species? Clin Microbiol Infect 2011; 17: 487-93

[26] Molloy PJ, Persing DH, Berardi VP. False-positive results of PCR testing for Lyme disease. Clin Infect Dis 2001; 33: 412-3

[27] Patel R, Grogg KL, Edwards WD, Wright AJ, Schwenk NM. Death from inappropriate therapy for Lyme disease. Clin Infect Dis 2000; 31: 1107-9

[28] Priem S, Rittig MG, Kamradt T, Burmester GR, Krause A. An optimized PCR leads to rapid and highly sensitive detection of Bor- 
relia burgdorferi in patients with Lyme borreliosis. J Clin Microbiol 1997; 35: 685-90

[29] Tamura K, Peterson D, Peterson N, Stecher G, Nei M, Kumar S. MEGA5: Molecular evolutionary genetics analysis using maximum likelihood, evolutionary distance, and maximum parsimony methods. Mol Biol Evol 2011; doi: 10.1093/molbev/msr121 [Epub ahead of print]

[30] Casjens S, Palmer N, van Vugt R, et al. A bacterial genome in flux: the twelve linear and nine circular extrachromosomal DNAs in an infectious isolate of the Lyme disease spirochete Borrelia burgdorferi. Mol Microbiol 2000; 35: 490-516.

[31] Garon CF, Dorward DW, Corwin MD. Structural features of Borrelia burgdorferi - the Lyme disease spirochete: silver staining for nucleic acids. Scanning Microsc 1989; 3: 109-15

[32] Lencáková DH, Schulte-Spechtel U, Fingerle V, Pet'ko B, Wilske B. Detection of a large linear plasmid in Borrelia spielmanii isolate. Can J Microbiol 2011; 57: 343-6

[33] Maraspin V, Ruzic-Sabljic E, Strle F. Lyme borreliosis and Borrelia spielmanii. Emerging Infect Dis 2006; 12: 1177

[34] Biškup UG, Strle F, Ružic-Sabljic E. Loss of plasmids of Borrelia burgdorferi sensu lato during prolonged in vitro cultivation. Plasmid 2011; 66: 1-6

[35] Walsh TR, Toleman MA. The new medical challenge: why NDM1? Why Indian? Expert Rev Anti Infect Ther 2011; 9: 137-41

[36] Barbour AG, Travinsky B. Evolution and distribution of the ospC gene, a transferable serotype determinant of Borrelia burgdorferi. mBio 2010; 1: e00153-10.

[37] Dorward DW, Garon CF. DNA is packaged within membranederived vesicles of gram-negative but not gram-positive bacteria. Appl Environ Microbiol 1990; 56: 1960-2

[38] Aberer E, Schmidt BL, Breier F, Kinaciyan T, Luger A. Amplification of flagellar and RNA polymerase $\mathrm{C}$ gene sequences of Borrelia burgdorferi in urine of patients with granuloma anulare and lichen sclerosus et atrophicus. Arch Dermatol 1999; 135: 210-2.

[39] Bergmann AR, Schmidt BL, Derler A-M, Arberer E. Importance of sample preparation for molecular diagnosis of Lyme borreliosis from urine. J Clin Microbiol 2002; 40: 4581-4

[40] Maiwald M, Stockinger C, Hassler D, von Knebel Doeberitz M, Sonntag HG. Evaluation of the detection of Borrelia burgdorferi DNA in urine samples by polymerase chain reaction. Infection 1995; 23: 173-9

[41] Schmidt BL, Muellegger RR, Stockenhuber C, et al. Detection of Borrelia burgdorferi-specific DNA in urine specimens from patients with erythema migrans before and after antibiotic therapy. $\mathrm{J}$ Clin Microbiol 1996; 34: 1359-63

[42] Li X, McHugh G, Damle N, Sikand VK, Glickstein L, Steere AC. Burden and viability of Borrelia burgdorferi in skin or joints, of patients with erythema migrans or lyme arthritis. Arthritis Rheum 2011; doi: 10.1002/art.30384. [Epub ahead of print]
[43] Kaberdin VR, Singh D, Lin-Chao S. Composition and conservation of the mRNA-degrading machinery in bacteria. J Biomed Sci 2011; 22: 18-23

[44] Aberer E, Bergmann AR, Derler A-M, Schmidt B. Course of Borrelia burgdorferi DNA shedding in urine after treatment. Acta Derm Venereol 2007; 87: 39-2

[45] Wagner EM, Schmidt BL, Bergmann AR, Derler AM, Arberer E. Inabilty of one-step real-time PCR to detect Borrelia burgdorferi DNA in urine. J Clin Microbiol 2004; 42: 938

[46] Zbinden R, Goldenberger D, Lucchini GM, Altwegg M. Comparison of two methods for detecting intrathecal synthesis of Borrelia burgdorferi-specific antibodies and PCR for diagnosis of Lyme neuroborreliosis. J Clin Microbiol 1994; 32: 1795-8

[47] Cerar T, Ogrinc K, Cimperman J, Lotric-Furlan S, Strle F, RuzicSabljic E. Validation of cultivation and PCR methods for diagnosis of Lyme neuroborreliosis J Clin Microbiol 2008; 46: 3375-9

[48] Bustin SA, Benes V, Garson JA, et al. The MIQE guidelines: Minimum information for publication of quantitative real-time PCR experiments. Clin Chem 2009; 55: 611-22

[49] Anonymous. Innovationsservice der Kassenärztlichen Bundesvereinigung (KBV); online brochure. 2010; http://www.kbv.de/veranstaltungen/innovationsservice.html download page for accessing the brochure; [last Accessed: July $16^{\text {th }}$ 2011].

[50] Crowder CD, Matthews HE, Schutzer S, et al. Genotypic variation and mixtures of Lyme Borrelia in Ixodes ticks from North America and Europe. PLoS One 2010; 5: 10650

[51] Crowder CD, Rounds MA, Phillipson CA, et al. Extraction of total nucleic acids from ticks for the detection of bacterial and viral pathogens. J Med Entomol 2010; 47: 89-94

[52] Elnifro EM, Ashshi AM, Cooper RJ, Klapper PE. Multiplex PCR: optimization and application in diagnostic virology. Clin Microbiol Rev 2000; 13: 559-70

[53] Kramer MF, Coen DM. Enzymatic amplification of DNA by PCR: standard procedures and optimization. Curr Protoc Immunol 2001; Chapter 10:Unit 10.20

[54] Wallet F, Loïez C, Herwegh S, Courcol RJ. Usefulness of real-time PCR for the diagnosis of sepsis in ICU-acquired infections. Infect Disord Drug Targets 2011 [Epub ahead of print]

[55] Jordan JA, Durso MB. Real-time polymerase chain reaction for detecting bacterial dna directly from blood of neonates being evaluated for sepsis. J Mol Diagn 2005; 7: 575-81

[56] Demaerschalck I, Messaoud AB, De Kesel M, et al. Simultaneous presence of different Borrelia burgdorferi genospecies in biological fluids of Lyme disease patients. J Clin Microbiol 1995; 33: 6028

[57] Nocton JJ, Dressler F, Rutledge B, et al. Detection of Borrelia burgdorferi DAN by polymerase chain reaction in synovial fluid from patients with Lyme arthritis. N Engl J Med 1994; 330: 229-34

This is an open access article licensed under the terms of the Creative Commons Attribution Non-Commercial License (http://creativecommons.org/licenses/by-nc/3.0/) which permits unrestricted, non-commercial use, distribution and reproduction in any medium, provided the work is properly cited. 